\title{
Transduction without Tip Links in Cochlear Hair Cells Is Mediated by Ion Channels with Permeation Properties Distinct from Those of the Mechano-Electrical Transducer Channel
}

\author{
Walter Marcotti, ${ }^{1,2 *}$ Laura F. Corns, ${ }^{2 *}$ Terri Desmonds, ${ }^{1 *}$ Nerissa K. Kirkwood, ${ }^{1}$ Guy P. Richardson, ${ }^{1}$ \\ and Corné J. Kros ${ }^{1,3}$ \\ ${ }^{1}$ Sussex Neuroscience, School of Life Sciences, University of Sussex, Falmer, Brighton BN1 9QG, United Kingdom, ${ }^{2}$ Department of Biomedical Science, \\ University of Sheffield, Sheffield, S10 2TN, United Kingdom, and ${ }^{3}$ Department of Otorhinolaryngology, Head and Neck Surgery, University Medical Center \\ Groningen, University of Groningen, 9700 RB Groningen, The Netherlands
}

Tip links between adjacent stereocilia are believed to gate mechano-electrical transducer (MET) channels and mediate the electrical responses of sensory hair cells. We found that mouse auditory hair cells that lack tip links due to genetic mutations or exposure to the $\mathrm{Ca}^{2+}$ chelator BAPTA can, however, still respond to mechanical stimuli. These MET currents have unusual properties and are predominantly of the opposite polarity relative to those measured when tip links are present. There are other striking differences, for example, the channels are usually all closed when the hair cell is not stimulated and the currents in response to strong stimuli can be substantially larger than normal. These anomalous MET currents can also be elicited early in development, before the onset of mechano-electrical transduction with normal response polarity. Current-voltage curves of the anomalous MET currents are linear and do not show the rectification characteristic of normal MET currents. The permeant MET channel blocker dihydrostreptomycin is two orders of magnitude less effective in blocking the anomalous MET currents. The findings suggest the presence of a large population of MET channels with pore properties that are distinct from those of normal MET channels. These channels are not gated by hair-bundle links and can be activated under a variety of conditions in which normal tip-link-mediated transduction is not operational.

Key words: aminoglycoside antibiotics; cochlea; hair cell; mechano-electrical transduction

\section{Introduction}

The tip links of sensory hair cells are composed of two members of the cadherin superfamily of cell-cell adhesion molecules, protocadherin 15 (PCDH15) and cadherin 23 (CDH23) (Söllner et al., 2004; Siemens et al., 2004; Ahmed et al., 2006). PCDH15 is located at the lower end of the tip link, whereas CDH23 is located at the upper end (Kazmierczak et al., 2007). The mechanoelectrical transducer (MET) channels are localized at the tips of the shorter stereocilia at the lower end of each link (Beurg et al.,

\footnotetext{
Received Sept. 23, 2013; revised Feb. 7, 2014; accepted March 3, 2014.

Author contributions: W.M., G.P.R., and C.J.K. designed research; W.M., L.F.C., T.D., N.K.K., G.P.R., and C.J.K. performed research; W.M., L.F.C., T.D., N.K.K., and C.J.K. analyzed data; W.M. and C.J.K. wrote the paper.

This work was supported by Grants from the MRC to C.J.K., and The Wellcome Trust to W.M. (091895) and G.P.R. (087737).

The authors declare no competing financial interests.

*W.M., L.F.C., and T.D. contributed equally to this work.

This article is freely available online through the J Neurosci Author Open Choice option.

Correspondence should be addressed to either of the following: Corné J. Kros, Sussex Neuroscience, School of Life Sciences, University of Sussex, Falmer, Brighton BN1 9QG, United Kingdom, E-mail: c.j.kros@sussex.ac.uk; or Walter Marcotti, Department of Biomedical Science, University of Sheffield, Sheffield S10 2TN, United Kingdom, E-mail: w.marcotti@sheffield.ac.uk.

D0I:10.1523/JNEUROSCI.4086-13.2014

Copyright @ 2014 Marcotti et al.

This is an Open Access article distributed under the terms of the Creative Commons Attribution License (http://creativecommons.org/licenses/by/3.0), which permits unrestricted use, distribution and reproduction in any medium provided that the original work is properly attributed.
}

2009). One would therefore expect hair cells in which PCDH15 or CDH23 are absent to lack MET currents. Unusual MET currents with abnormal directional sensitivity have, however, been observed in outer hair cells (OHCs) of Pcdh15 and Cdh 23 mutant mice, suggesting MET channels can be gated by means other than via tip links (Alagramam et al., 2011). By examining the characteristics of MET currents that can be elicited under a variety of conditions in cochlear hair cells that lack normal tip links, we show that this phenomenon is not restricted to hair cells with mutations in tip-link proteins. Our results reveal that the pore properties of the underlying ion channels are different from those of the normal MET channels of cochlear hair cells.

\section{Materials and Methods}

OHCs and inner hair cells (IHCs) from CD-1 and C57BL/6J mice of either sex were studied from embryonic day (E)18.5 to postnatal day (P) 10 where the day of birth (P0) corresponds to E19.5. Recordings were performed from acutely dissected organs of Corti (Marcotti et al., 2003) or in organotypic cultures (Russell and Richardson, 1987) that had been maintained for 1-3 d in vitro. Most recordings were made from hair cells situated in the apical coil. When recordings from basal-coil hair cells are reported this is stated explicitly. Some recordings were of OHCs from homozygous Myo7a $a^{6 J}, M y o 7 a^{4626 S B}, C d h 23^{v 2 J}$, and Pcdh15 $5^{\text {av3J }}$ mutant mice (Kros et al., 2002; Alagramam et al., 2011). For experiments with embryos, mice were paired overnight and checked for vaginal plugs the following morning. Assuming ovulation occurs midway through the 
dark cycle, the mid-point of the light cycle of the day following mating is considered to be E0.5. Adult and neonatal mice were killed by cervical dislocation and embryos by decapitation, in accordance with UK Home Office regulations.

For the experiments using acutely isolated organs of Corti, cochleae were dissected in normal extracellular solution (in $\mathrm{mm}$ ): $135 \mathrm{NaCl}$, $5.8 \mathrm{KCl}, 1.3 \mathrm{CaCl}_{2}, 0.9 \mathrm{MgCl}_{2}, 0.7 \mathrm{NaH}_{2} \mathrm{PO}_{4}$, 5.6 D-glucose, 10 HEPES-NaOH. Sodium pyruvate $(2 \mathrm{mM})$, MEM amino acids solution (50×, without L-glutamine), and MEM vitamins solution $(100 \times)$ were added from concentrates (Fisher Scientific). The $\mathrm{pH}$ was adjusted to 7.5 (osmolality $\sim 308 \mathrm{mmol} \mathrm{kg}{ }^{-1}$ ). The dissected organs of Corti were transferred to a microscope chamber and immobilized using a nylon mesh fixed to a stainless steel ring. Where organotypic cultures were used, they were transferred to the microscope chamber on their collagen substrate and did not require further immobilization. The chamber was continuously perfused with the above extracellular solution. The organs of Corti were observed with an upright microscope (Zeiss, Leica) with Nomarski differential interference contrast optics ( $40 \times$ or $63 \times$ water-immersion objectives). Whole-cell patch-clamp recordings were performed at room temperature using EPC-8 (HEKA) or Optopatch (Cairn Research) patch-clamp amplifiers. Patch pipettes (2-3 $\mathrm{M} \Omega$ ) contained the following (in $\mathrm{mM}$ ): 135 $\mathrm{CsCl}$ (or 106 Cs-glutamate, $20 \mathrm{CsCl}$ ), 2.5 $\mathrm{MgCl}_{2}, 1$ EGTA-CsOH, $2.5 \mathrm{Na}_{2} \mathrm{ATP}, 10$ sodium phosphocreatine, 5 HEPES-CsOH, pH 7.3. Patch pipettes were coated with surf wax $(\mathrm{Mr}$ Zogs SexWax) to minimize the fast capacitance transient across the wall of the patch pipette.

MET currents were elicited by stimulating the hair bundles of OHCs and IHCs using a fluid jet from a pipette (tip diameter 8-10 $\mu \mathrm{m}$ ) driven by a piezoelectric disc (Kros et al., 1992; Marcotti et al., 2005). The tip of the pipette delivering the fluid jet was positioned near to the bundles to elicit a maximal MET current. Mechanical stimuli (filtered at 0.5-1.0 $\mathrm{kHz}, 8$-pole Bessel) were applied as 45 or $50 \mathrm{~Hz}$ sinusoids with driver voltage amplitudes of $\pm 25-50 \mathrm{~V}$, or as $50 \mathrm{~ms}$ steps. The fluid jet was positioned at the modiolar side of the hair bundles and positive driver voltage (fluid flowing out of the jet) corresponds to force that moves the bundle laterally toward the stria (i.e., toward the kinocilium in an intact, normal bundle). Note that this definition is different from that used by Kros et al. (2002), where positive driver voltage or displacement indicates excitatory stimuli that open the MET channels, regardless of the direction of the force or bundle movement: response polarity was not explicitly considered due to uncertainty about the orientation of the disorganized hair bundles. In some experiments, bundle movements were recorded with a laser differential interferometer (Géléoc et al., 1997) or the fluid jet was placed orthogonal to the axis of sensitivity of the hair bundle. Stimulation with a fluid jet instead of a rigid probe (Kennedy et al., 2003) was preferred because it allows a more accurate measure of the resting MET current. Currents were acquired using either Asyst (Keithley Instruments) or pClamp (Molecular Devices) software, filtered between 2.5 and $5 \mathrm{kHz}$, sampled between 5 and 50 $\mathrm{kHz}$ and stored on computer for off-line analysis. Membrane potentials were corrected for liquid junction potentials of either $-4 \mathrm{mV}$ (CsCl-based) or $-11 \mathrm{mV}$ (Cs-glutamate-based intracellular solution) measured between pipette and bath solutions. Superfusion of BAPTA-containing extracellular solution (in mM: $141 \mathrm{NaCl}, 5.8 \mathrm{KCl}, 0.7 \mathrm{NaH}_{2} \mathrm{PO}_{4}, 5.6$ D-glucose, 10 HEPES$\mathrm{NaOH}, 5 \mathrm{Na}_{4} \mathrm{BAPTA}$ ) was maintained (for up to $45 \mathrm{~min}$ ) throughout most of the recordings aimed at tracking the time course of the appearance of the anomalous MET current following tip-link rupture. For some experiments,
B
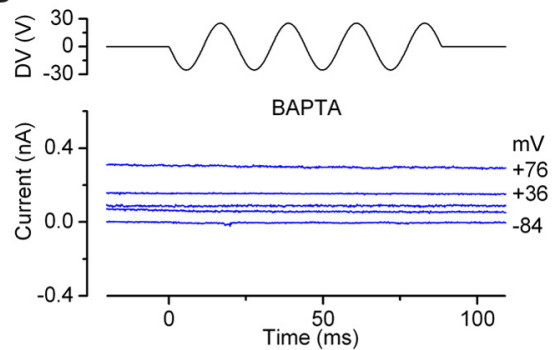

D

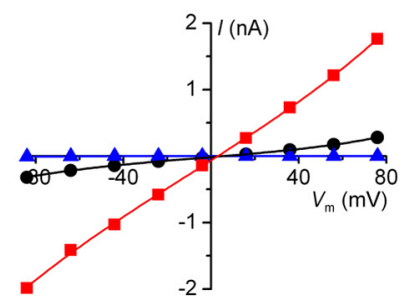

50 formed at room temperature as previously described (Gale et al., 2001).

For the experiments investigating the pore properties of the channels, the aminoglycoside antibiotic dihydrostreptomycin (DHS) was locally superfused at concentrations ranging from $10 \mu \mathrm{M}$ to $10 \mathrm{~mm}$. Dose-response curves were fitted with the Hill equation:

$$
\frac{I_{\mathrm{DHS}}}{I_{\mathrm{c}}}=\frac{1}{1+\left(\frac{\left[D_{\mathrm{o}}\right]}{K_{\mathrm{D}}}\right)^{n_{\mathrm{H}}}}
$$

where $I_{\mathrm{DHS}}$ is the current in the presence of DHS, $I_{\mathrm{c}}$ is the control current, $K_{\mathrm{D}}$ is the dissociation constant, $\left[D_{\mathrm{o}}\right]$ the concentration of DHS and $n_{\mathrm{H}}$ is the Hill coefficient. Stocks of DHS (molecular weight 730.7) were prepared at $10 \mathrm{~mm}$ (for final concentrations up to and including $300 \mu \mathrm{M}$ ) and $100 \mathrm{~mm}$. Tip links were severed by bath perfusion of extracellular solution containing $5 \mathrm{~mm}$ BAPTA for $5 \mathrm{~min}$. In a few experiments, neomycin (molecular weight 908.9) was used to study MET current block of homozygous $M y o 7 a^{4626 S B}$ mutant mice.

The fits through the current-voltage curves are according to a singleenergy-barrier model:

$$
I(V)=k\left[\exp \frac{(1-\gamma)(V-V r)}{V s}-\exp \frac{-\gamma(V-V r)}{V s}\right],
$$

where $k$ is a proportionality constant, $V_{r}$ is the reversal potential, $V_{s}$ is a measure for the steepness of the rectification, and $\gamma$ is the fractional distance within the membrane's electrical field of an energy barrier, as measured from the outside (Kros et al., 1992), or to a straight line, as appropriate. The size of the developing MET currents was fitted with a sigmoidal growth curve:

$$
I=I_{\max } /\left(1+\exp -\frac{t-t_{1 / 2}}{S}\right)
$$


A

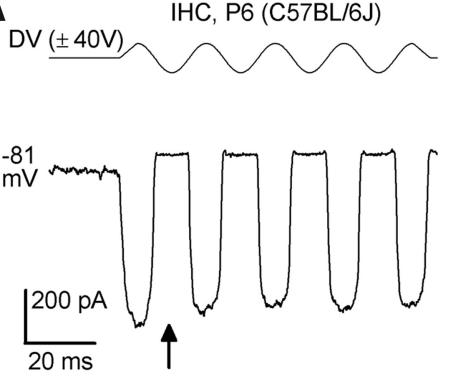

B

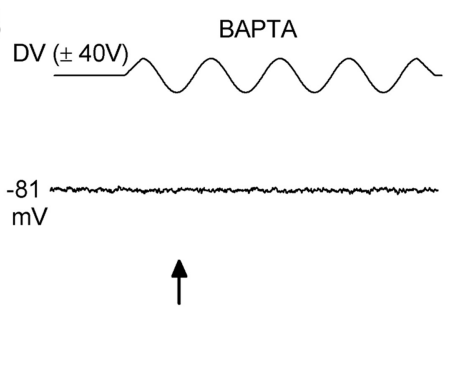

C $D V( \pm 40 \mathrm{~V})$

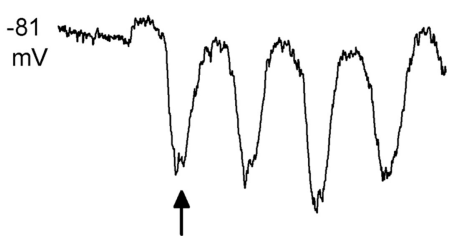

Figure 2. MET currents of IHCs before and during BAPTA treatment. $A$, Saturating MET currents recorded from a P6 IHC of a wild-type C57BL/6J mouse, at a membrane potential of $-81 \mathrm{mV}$. The driver voltage (DV: $50 \mathrm{~Hz}$ sinusoid, $40 \mathrm{~V}$ amplitude) to the fluid jet is shown above the current trace. $B$, No MET currents were recorded upon superfusion of 5 mM BAPTA. C, MET currents recorded from the same IHC shown in $\boldsymbol{B} 4 \mathrm{~min}$ after the start of BAPTA application and after moving the fluid jet very close to the bundle until anomalous currents were seen. Anomalous currents were elicited during negative stimuli. Arrows point to peak of negative phase of first sinusoid.

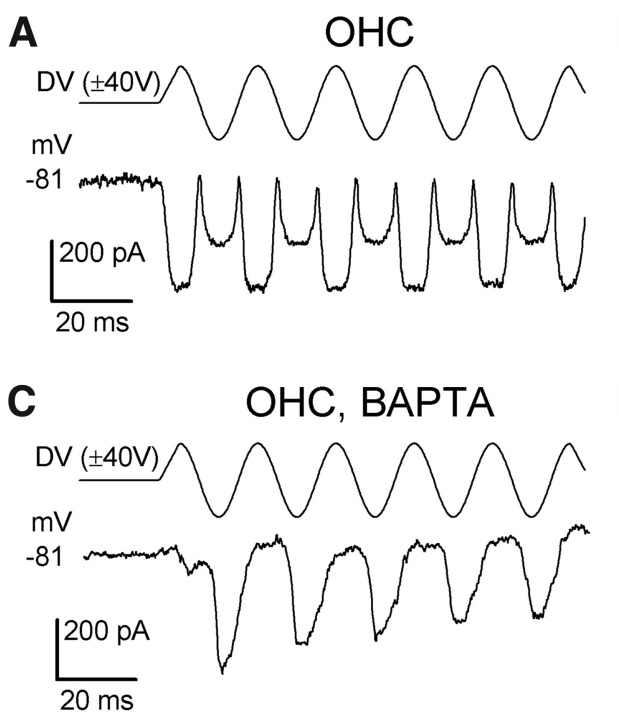

B

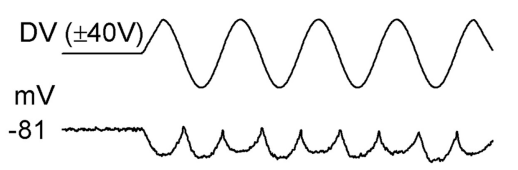

$\frac{200 \mathrm{pA}}{20 \mathrm{~ms}}$
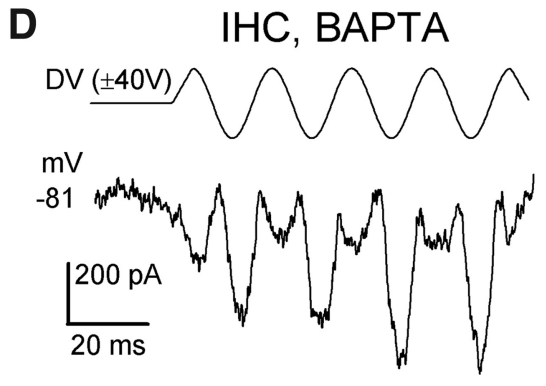

Figure 3. MET currents in response to orthogonal hair-bundle stimulation. $A, B$, Saturating MET currents recorded from a P7 $\mathrm{OHC}(\boldsymbol{A})$ and a P5 IHC ( $\boldsymbol{B})$ of wild-type C57BL/6J mice, at a membrane potential of $-81 \mathrm{mV}$. The fluid jet (DV: $50 \mathrm{~Hz}$ sinusoid, $40 \mathrm{~V}$ amplitude, top) was positioned orthogonally to the axis of mechanical sensitivity of the hair bundle. $C, D, M E T$ currents recorded from a P7 OHC (C) and a P6 IHC (D) $\sim 5$ min after the start of BAPTA application and after moving the fluid jet very close to the bundle until anomalous currents were seen.

where $t_{1 / 2}$ is the age at which half the maximal current is reached and $s$ is the slope, a measure for the steepness of growth. Means are reported as $\pm \mathrm{SEM}$ in text and figures.

\section{Results}

MET currents in OHCs and IHCs after cleaving tip links with BAPTA

Exposure of hair bundles to the $\mathrm{Ca}^{2+}$ chelator BAPTA cuts both the tip links and the kinocilial links (Assad et al., 1991; Crawford et al., 1991; Goodyear and Richardson, 2003). Before the application of $5 \mathrm{~mm}$ BAPTA, a sinusoidal force stimulus from a fluid jet in the positive direction (toward the kinocilium) elicited large MET currents in wild-type OHCs from CD-1 or C57BL/6J mice, whereas negative stimuli closed the fraction of the MET current activated at rest (Fig. 1A). The currents reversed near $0 \mathrm{mV}$ and the resting MET current increased at positive potentials, presumably due to a reduction in $\mathrm{Ca}^{2+}$-dependent adaptation (Crawford et al., 1989). Upon application of $5 \mathrm{~mm}$ BAPTA the MET currents briefly increased in size in some cells (from -670 to $-1380 \mathrm{pA}$ in one $\mathrm{OHC}$, and from -883 to $-1630 \mathrm{pA}$ in another, both at $-124 \mathrm{mV}$; data not shown) due to a reduction of the

permeant block by $\mathrm{Ca}^{2+}$ ions in the channel pore, before disappearing within $10 \mathrm{~s}$ (Fig. $1 B$ ). On applying strong mechanical stimulation in the continuing presence of BAPTA, mechanosensitive currents were elicited that could be larger than normal MET currents (Fig. 1C,D), up to $-2 \mathrm{nA}$ at $-84 \mathrm{mV}$. The currents were not activated at the resting position of the bundle and occurred preferentially in response to negative force stimuli. During a recording from any given cell, currents were quite variable in size, likely due to the difficulty of applying strong enough mechanical stimulation, and in their directional sensitivity (see below).

In P6-P9 IHCs $(n=6)$, BAPTA treatment of normally transducing cells (Fig. $2 A$ ) also resulted in anomalous MET currents (recorded in the continuing presence of BAPTA) that were elicited during the negative phase of the sine-wave stimulus $(-464 \pm 146 \mathrm{pA}$ at $-84 \mathrm{mV}$, range -65 to $-1140 \mathrm{pA}, n=6$ ) following a period in which no MET current could be evoked (Fig. 2 B, C). The size of the anomalous MET current was comparable to, but more variable than, the size of the normal MET current in control P6-P9 IHCs $(-642 \pm 33 \mathrm{pA}$ at $-84 \mathrm{mV}$, range -525 to $-708 \mathrm{pA}, n=5)$. In contrast to the anomalous current seen in OHCs, two of six IHCs recorded from in the presence of BAPTA (Fig. $2 C)$ had a small resting current $(1.6 \pm 1.1 \%$ of the maximum current) at $-84 \mathrm{mV}$. All five control IHCs had a resting MET current $(3.3 \pm 1.6 \%)$.

It was of interest to establish whether the anomalous MET currents were related at all to the axis of mechanical sensitivity of the hair bundle. We investigated this by stimulating the hair bundle of some OHCs and IHCs with the fluid jet positioned orthogonally to this axis before and during superfusion with $5 \mathrm{~mm}$ BAPTA. The results were not entirely straightforward because, even before BAPTA, inward MET currents were observed in OHCs (Fig. 3A) and IHCs (Fig. 3B) both for fluid flowing out of (positive-driver voltage) and into (negative-driver voltage) the jet. These bidirectional responses were presumably due to both halves of the $\mathrm{V}$-shaped (OHCs) or more rounded (IHCs) bundle responding to the vectorial force directed along the axis toward 
the kinocilium. During application of BAPTA the anomalous MET current could be observed, to a variable extent, in both phases of the stimulus for OHCs and IHCs (Fig. $3 C, D$, respectively). The maximum size of the anomalous MET currents recorded at $-84 \mathrm{mV}$ with orthogonal bundle stimulation during BAPTA application was $-416 \pm 139 \mathrm{pA}$ for three OHCs and $-430 \pm 168 \mathrm{pA}$ for four IHCs. The finding of bidirectional anomalous MET currents in response to orthogonal stimulation, while not conclusive, is at least consistent with the gating of the anomalous MET currents being indeed related to the axis of mechanical sensitivity of normal, tip-link gated MET currents, but with responses predominantly in the opposite direction.

\section{Gating and kinetics of anomalous MET currents}

These anomalous MET currents recorded during or after BAPTA application closely resembled MET currents reported in homozygous $C d h 23^{v 2 J}$ and Pchd $15^{a v 3 J} \mathrm{mu}-$ tant mice that lack tip links (Alagramam et al., 2011) and in $M y o 7 a^{6 J}$ mutant mice lacking functional myosin VIIA (MYO7A) (Kros et al., 2002). Indeed, we still observed large anomalous MET currents in OHCs of homozygous Cdh $23^{v 2 J} \mathrm{mu}-$ tants in the continuous presence of $5 \mathrm{~mm}$ extracellular BAPTA (Fig. $4 A, B$ ). Similar findings were made in an additional three OHCs. We also found that the currents of OHCs from homozygous $M y o 7 a^{6 J}$ mice $(n=6)$ were resistant to treatment with $5 \mathrm{~mm}$ BAPTA and $50 \mu \mathrm{g} / \mathrm{ml}$ subtilisin applied simultaneously (Fig. $4 C, D$ ), suggesting that the underlying ion channels are not gated by tip links, kinocilial links or ankle links (Goodyear and Richardson, 2003; Goodyear et al., 2005). Figure 4C provides an example of an observation that was also made in many other hair cells, namely that a smaller current of a similar "peaky" shape at negative potentials (the size of which could vary markedly during a recording in a given cell) was also seen in response to positive stimuli, so that a sine-wave stimulus resulted in current responses with double the stimulus frequency (" $2 \mathrm{f}$ ” responses). In a few cells the anomalous response (in terms of absence of a resting MET current, size and kinetics: see further on) was to positive stimuli, just as for the normal MET current (this was observed in three homozygous mutant OHCs: one Cdh23 $3^{v 2 J}$ and two $M y o 7 a^{6 J}$ ).

Interestingly, the MET currents recorded in response to step stimuli still showed evidence of strong "adaptation," a decline in current over time, at $-84 \mathrm{mV}$, but not $+86 \mathrm{mV}$, in the presence of $5 \mathrm{~mm}$ BAPTA in both the Cdh23 $3^{v 2 J}$ and $M y_{0} 7 a^{6 J}$ homozygotes. Figure 5 shows recordings from a homozygous $C d h 23^{v 2 J} \mathrm{OHC}$ at hyperpolarized and depolarized membrane potentials. The step responses in this cell correspond to the responses observed to sine-wave stimuli, with the largest currents elicited by negative force steps (Fig. 5A,B) and smaller currents with similar kinetics seen in response to positive force steps (Fig. $5 C, D$ ). For both stimulus directions and at both potentials, $\sim 50 \mathrm{~nm}$ of bundle displacement is required before a current occurs (Fig. 5E). The decline in current is as reported before for these mutants in normal extracellular $\mathrm{Ca}^{2+}$ (Kros et al., 2002; Alagramam et al., 2011), and shows that in these cells this phenomenon does not depend on influx of extracellular $\mathrm{Ca}^{2+}$. The onset kinetics of the currents were also slowed compared with normal MET currents, and as noted before for these mutants this feature is particularly evident at depolarized membrane potentials (Fig. $5 B, D$ ).

The anomalous MET currents likely represent a population of MET channels that are gated by mechanisms other than by tip links. To further substantiate this idea we sought to irreversibly damage the hair bundles of normal OHCs by mechanical overstimulation. After doing so we were able to record the anomalous currents following a time interval of between $7 \mathrm{~s}$ and $3 \mathrm{~min}$ (Fig. $6 A-C$ ). Such responses were often unstable during a recording, varying in size and in the degree to which a component responding to positive stimuli was present. Figure $6 D-F$ shows an example of a cell in which a $2 \mathrm{f}$ response was recorded transiently before the currents occurred only in response to negative force stimuli.

The anomalous currents could thus be elicited under a variety of conditions: after cleaving the tip links with BAPTA, in mutants lacking functional tip links, and following mechanical overstimulation and destruction of the hair bundle. The responses were usually, but not always, largest for negative force stimuli and a resting MET current could not be observed at hyperpolarized membrane potentials. The threshold for eliciting the anomalous currents at $-84 \mathrm{mV}$ was some -50 to $-150 \mathrm{~nm}$. When applying force steps, currents developed more slowly than normal and an unusually strong decline was observed at negative potentials (Kros et al., 2002; Alagramam et al., 2011). 


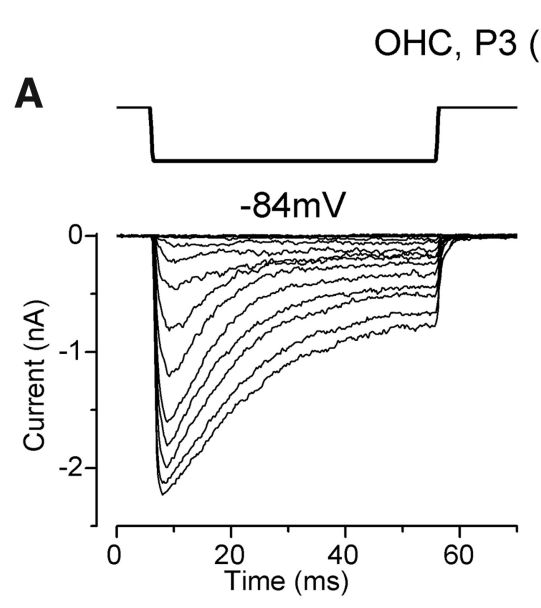

$\left(C^{2} 23^{\text {22j }}\right)$ - BAPTA
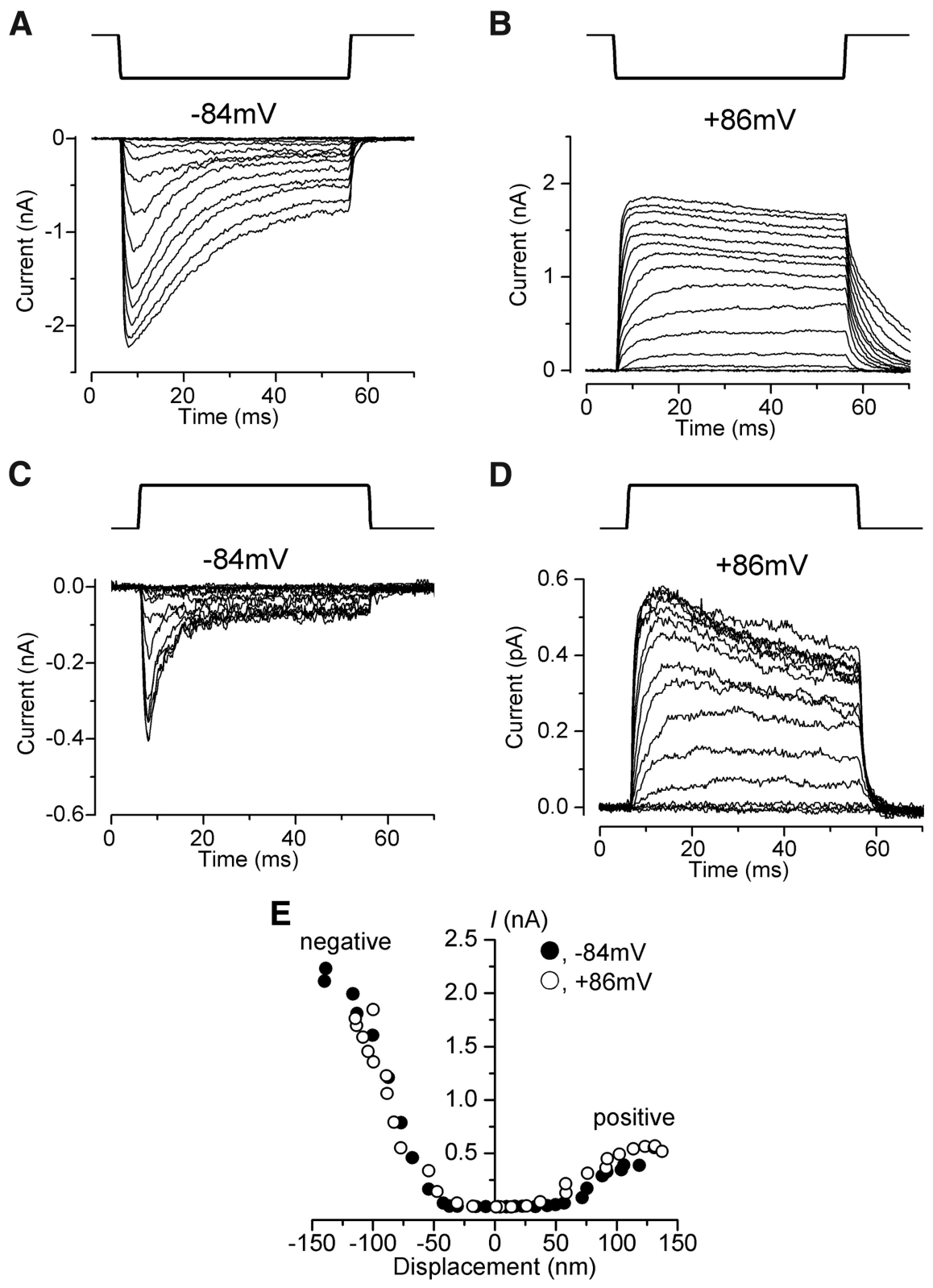

Figure 5. Anomalous MET currents in a $C d h 23^{v j 2} \mathrm{OHC}$ in response to force steps. $\boldsymbol{A}, \boldsymbol{B}$, Large MET currents elicited using force steps in the negative direction at membrane potentials of $-84 \mathrm{mV}$ and $+86 \mathrm{mV}$, respectively, from a P3 apical-coil $\mathrm{OHC}$ of a Cdh $23^{\text {vi2 }}$ mouse. Currents decline strongly at $-84 \mathrm{mV}$ but not at $+86 \mathrm{mV}$. C, D, Smaller MET currents were elicited using force steps in the positive direction at membrane potentials of $-84 \mathrm{mV}$ and $+86 \mathrm{mV}$, respectively, from the same $\mathrm{OHC}$ as $\boldsymbol{A}$ and $\boldsymbol{B}$. Note different scale of ordinates. Direction of force steps indicated at the top of panels $\boldsymbol{A}-\boldsymbol{D}$. $\boldsymbol{E}$, Absolute size of peak MET current as a function of bundle displacement to the fluid jet at $-84 \mathrm{mV}$ (closed circles) and $+86 \mathrm{mV}$ (open circles), for a range of force steps.

\section{Development of normal and anomalous OHC MET currents}

We hypothesized that these unusual currents might represent a population of MET channels in an abnormal position that is not gated via the tip-link complex and wondered whether the development of these currents matched that of the normal MET currents. In the apical coil before P2, MET currents are absent or very small in rat (Waguespack et al., 2007) and mouse (Lelli et al., 2009; Kim and Fettiplace, 2013) OHCs. Tip links, although already present in apical mouse OHCs by E17.5, the earliest age examined (Goodyear et al., 2005), are hard to identify unequivocally at this early stage of development due to the presence of transient lateral links (Goodyear et al., 2005; Waguespack et al.,
2007). We followed the development of normal (Fig. $7 A, B$ ) and anomalous (Fig. $7 C-F$ ) MET currents in apical OHCs between E18.5 and P10. The former developed as reported previously with little or no current until P2, and half-maximum size was reached at P3.6 (Fig. 7B). Following application of $3 \mu \mathrm{M}$ FM1-43 for $10 \mathrm{~s}$ (Gale et al., 2001) dye loading was not observed in OHCs (and IHCs) before P2 in the apical coil (data not shown), indicating the absence of channels with a significant probability of being open when the bundles are in their resting position. Anomalous MET currents were already observed at E18.5 in apical-coil OHCs of wild-type mice, sized from -30 to -500 $\mathrm{pA}$ at $-84 \mathrm{mV}$ (Fig. 7C), and could be elicited by strong mechanical stimuli at a time when normal MET currents were still absent or very small (a few tens of pA). In a sample of $19 \mathrm{E} 18.5$ to P1 OHCs from wild-type CD-1 mice only three cells had small normal MET currents $(<-30 \mathrm{pA}$ at $-84 \mathrm{mV})$, whereas strong stimulation elicited the anomalous MET current in 11 cells. One cell first showed a small normal MET current $(-35 \mathrm{pA})$ followed by a small anomalous current $(-30 \mathrm{pA})$ during strong stimulation. By P3-P4 the vast majority of cells expressed normal MET currents (Fig. $7 A, B$ ). A set of recordings in which $214 \mathrm{P} 3-\mathrm{P} 4 \mathrm{OHCs}$ situated in the apical and basal coils of CD-1 mice were stimulated with $40 \mathrm{~V}$ sinusoids to elicit saturating MET currents was scrutinized for anomalous MET currents. Four of these cells only showed anomalous MET currents, whereas normal and anomalous MET currents were recorded simultaneously in another six cells. Overall, anomalous MET currents were thus observed rarely under these conditions, in $<5 \%$ of OHCs. Following BAPTA treatment to sever the tip links however, we reliably observed large anomalous currents in wildtype OHCs between P3 and P10 (Fig. $7 C, D)$. Current size was very variable but there was no obvious trend with age. This also applied to anomalous MET currents recorded between $\mathrm{P} 1$ and $\mathrm{P} 5$ from homozygous mutant mice with hair-bundle defects (Fig. 7E,F). Force steps revealed the characteristic strong current decline at negative potentials and the slow onset kinetics in developing $\mathrm{OHCs}$ from wild-type mice before the onset of normal MET currents (Fig. 8), as reported before for mutant OHCs with hairbundle defects (Kros et al., 2002; Alagramam et al., 2011).

Permeation properties of the anomalous channels differ from those of normal MET channels

The rare recordings of OHCs in which anomalous and normal MET currents coexisted offered an opportunity to compare their properties under identical conditions. In these cases the anoma- 
lous currents can be distinguished from the normal MET currents by their peaky appearance due their strong and rapid decline at negative membrane potentials, and by their occurrence during the negative phase of the stimulus waveform (Fig. $9 A, B)$. The normal MET current is more rounded in appearance at all potentials, and is partially activated at rest as indicated by the reduction of the holding current during the first negative half-cycle of the sine wave. When plotting the currentvoltage relation of the anomalous and normal MET currents in 4 OHCs which were studied in $1.3 \mathrm{~mm}$ extracellular $\mathrm{Ca}^{2+}$ (Fig. 9C), we noticed that the normal double-rectification (inward and outward), which has been attributed to a voltage-dependent block by divalent cations (Kros et al., 1992), is not a feature of the anomalous current. The normal current could be fitted with the singleenergy-barrier model used before (Kros et al., 1992; Gale et al., 2001; Marcotti et al., 2005), but the anomalous currents could not and were better fitted with a straight line. This finding suggests that the ion channel that underlies the anomalous MET current may have ion permeation characteristics that are different from those of the normal MET channels.

To gain a more detailed impression of the properties of the conducting pore of the ion channels that carry the anomalous MET currents, we examined block of the currents by the aminoglycoside antibiotic DHS. This has been studied in detail for normal MET currents, for which the half-blocking concentration at a membrane potential of $-84 \mathrm{mV}$ was reported as $7.0 \mu \mathrm{M}$ (Marcotti et al., 2005). Superfusion of $100 \mu \mathrm{M}$ DHS caused only a modest reduction of the MET currents recorded from OHCs after their tip links had been broken by exposure to $5 \mathrm{~mm}$ BAPTA with, as for the normal MET currents, the block being relieved at depolarized membrane potentials (Fig. 10A-C). Considerably higher concentrations of DHS, in the millimolar range, were required to achieve a nearly complete block at hyperpolarized membrane potentials, which was again largely removed upon depolarization (Fig. 10D-F; an OHC superfused with $3 \mathrm{~mm}$ DHS). Such concentrations, when applied to control OHCs, caused a rapid deterioration of the cells precluding successful patch-clamp recordings. In control experiments run in parallel with normal, non-BAPTA-treated OHCs, $10 \mu \mathrm{M}$ DHS caused a substantial block at hyperpolarized membrane potentials that was relieved at positive, and also extreme negative, potentials (Fig. 10G-I). Such relief of block at extreme negative membrane potentials, the signature for permeant block of the MET channel (Gale et al., 2001; Marcotti et al., 2005; van Netten and Kros, 2007), was not observed for the anomalous MET currents (Fig. 10C,F). DHS block was found to be reversible upon washout of the drug, both for anomalous and normal MET currents. The dose-responses curves for DHS block of the anomalous MET currents were shifted by two orders of magnitude compared with those of the normal MET currents (Marcotti et al., 2005), with half-blocking concentrations $\left(\mathrm{K}_{\mathrm{D}}\right)$ of $894 \mu \mathrm{M}$ and $7.0 \mu \mathrm{M}$ at $-84 \mathrm{mV}$, respectively. At -164 $\mathrm{mV}$ the $\mathrm{K}_{\mathrm{D}}$ became $11.4 \mu \mathrm{M}$ for the normal MET currents due to partial release of block, but such a shift did not occur for the anomalous MET currents $\left(\mathrm{K}_{\mathrm{D}} 832 \mu \mathrm{M}\right)$.
B

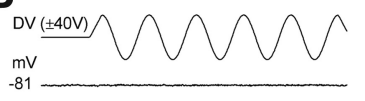

C

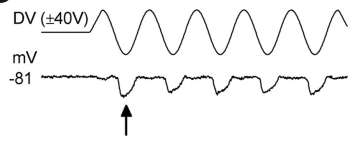

E

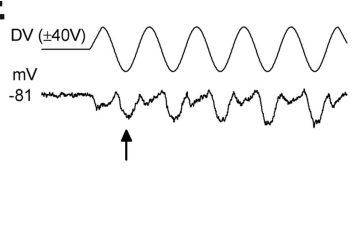

$\mathbf{F}$

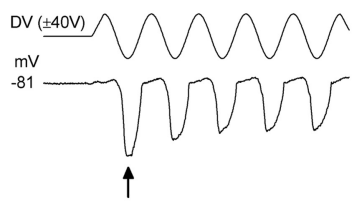

Another aminoglycoside antibiotic, neomycin, also caused little block of the anomalous MET currents of OHCs of homozygous $M y o 7 a^{6 J}$ and $M y o 7 a^{4626 S B}$ mutant mice (1 mM blocked $32.89 \pm 0.04 \%, n=3$, of the anomalous current at $-84 \mathrm{mV})$. Just as for DHS, block was considerably reduced compared with normal MET currents in three control OHCs from P6 CD-1 mice (100 $\mu \mathrm{M}$ blocked $72.1 \pm 2.4 \%, n=3$ ).

\section{Discussion}

\section{Anomalous MET currents of OHCs and IHCs}

Our observations show that MET channels in mammalian auditory hair cells can be gated when tip links are removed pharmacologically or are destroyed by repeated mechanical overstimulation. The currents measured under these conditions are of abnormal polarity in that they are elicited predominantly when the bundle is moved away from the kinocilium, and their onset kinetics are slower than normal. At negative membrane potentials, there is little or no resting transducer current and responses to a step stimulus decline rapidly, even for large stimuli. This decline is unlike classic MET current adaptation in that it does not depend on influx of extracellular $\mathrm{Ca}^{2+}$ through the MET channels (Crawford et al., 1989, 1991; Beurg et al., 2010; but see Peng et al., 2013). We could also elicit currents with these characteristics before the time at which normal MET currents are reported to appear during development (Waguespack et al., 2007; Lelli et al., 2009; Kim and Fettiplace, 2013). Finally, such currents are observed in OHCs of mutant mice that lack either of the two tip-link proteins, CDH23 or PCDH15 (Alagramam et al., 2011), or the tip-link-associated motor protein MYO7A (Kros et al., 2002; Grati and Kachar, 2011). Our present finding that the anomalous MET currents in the OHCs of homozygous $M y o 7 a^{6 J}$ mutant mice are resistant to BAPTA treatment (Fig. 4C) prompts a reinterpretation of the findings reported by Kros et al. (2002). We must now conclude that the MET currents in these mutants are not gated by means of tip links and are predominantly of opposite polarity relative to normal MET currents. The resistance of the currents to BAPTA and subtilisin, as well as their presence even in bundles that have been mechanically destroyed, would also seem to exclude gating by any of the other links that are situated in the hair bundle at this stage of development (Goodyear et al., 2005). 
A

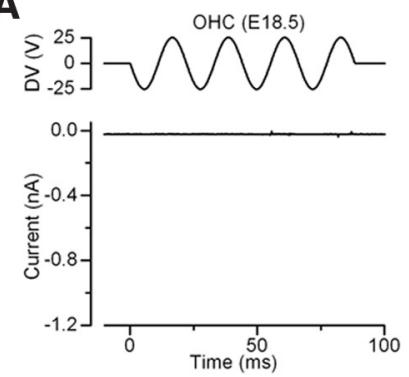

C

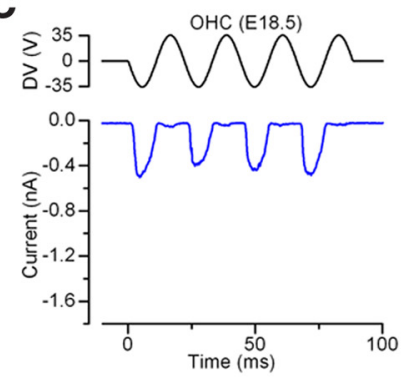

E

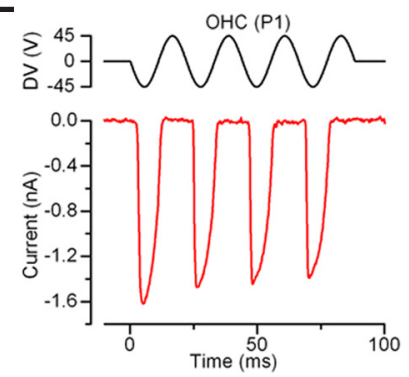

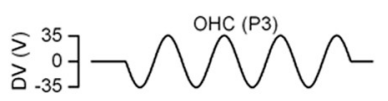
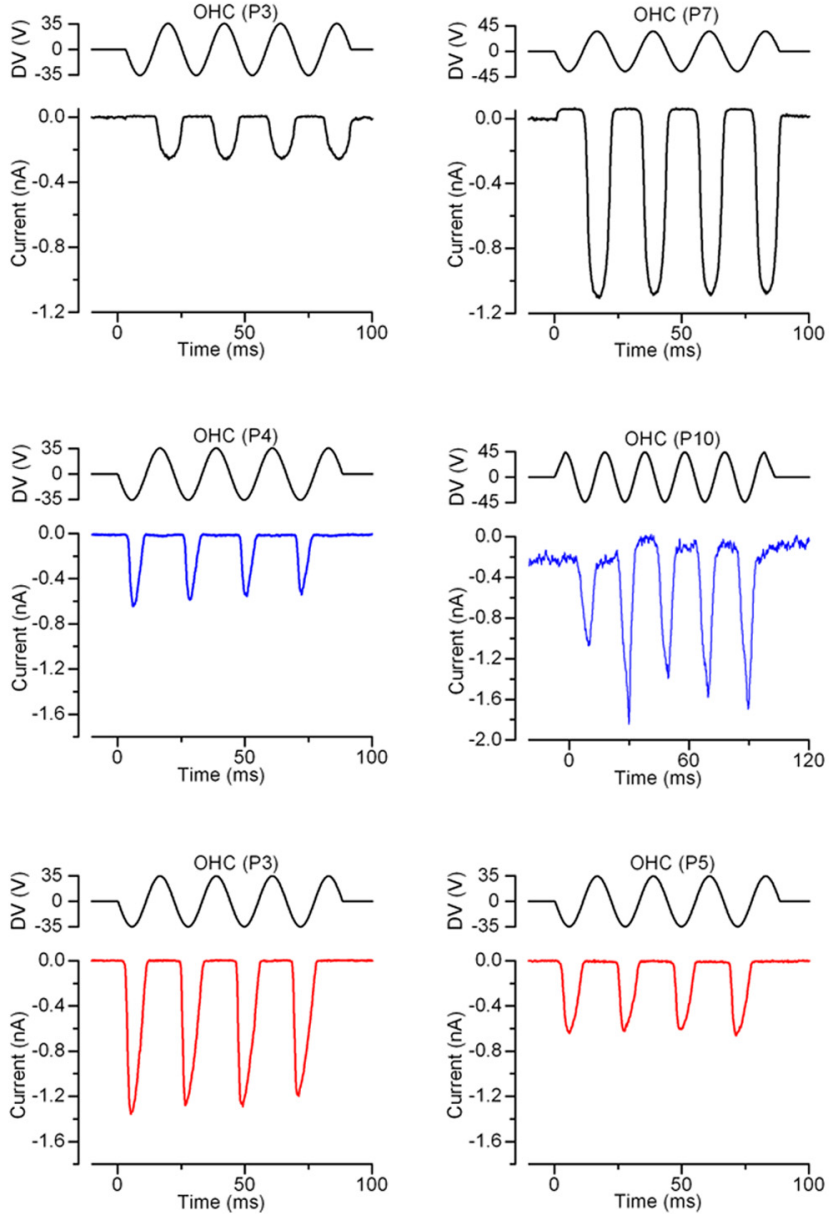

B

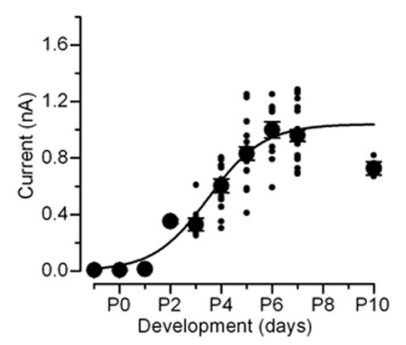

D

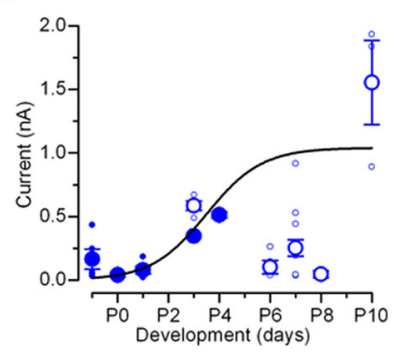

$\mathbf{F}$

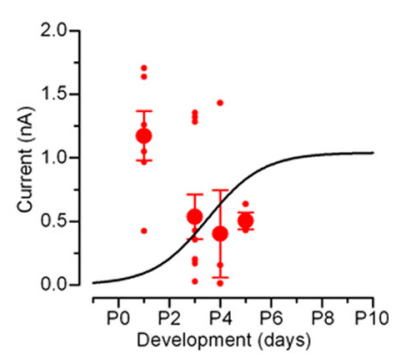

Figure 7. Development of the MET current in OHCS. $A$, Saturating MET currents elicited during positive bundle deflection from $0 H C$ of wild-type mice at different ages. $B$, Development of the maximum amplitude of the normal MET current (absolute size plotted, number of cells from left: 7,4,1,3,8,11,19,13,21,3) from E18.5 up to P10. Single data points at each age, in this and following panels, are shown with small filled or open circles. The fit to the data in controls is a sigmoidal growth curve, with half-maximal activation of $3.6 \mathrm{~d}$ and slope of $1.1 \mathrm{~d}$ (see Materials and Methods). C, Maximum anomalous MET current elicited during negative bundle deflection from $\mathrm{OHCs}$ from wild-type mice at different ages. E18.5 and P4 OHCs with spontaneous anomalous currents, P10 OHC after BAPTA treatment. D, Anomalous MET currents recorded in $\mathrm{OHCs}$ as a function of age without treatment (blue closed symbols:5,3,5,1,2) or after exposure to $5 \mathrm{~mm}$ BAPTA (blue open symbols:4,4,8,4,3). $E$, Anomalous MET currents recorded from OHCs

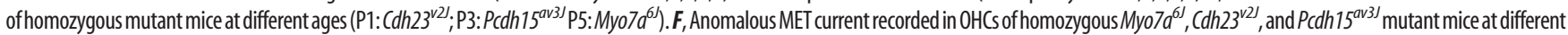
ages (red symbols: 6,10,4,3). Fit to control data from panel $\boldsymbol{B}$ superimposed on $\boldsymbol{D}$ and $\boldsymbol{F}$ for comparison. All currents from apical-coil $0 \mathrm{HC}$, recorded at $-84 \mathrm{mV}$.

\section{Location of the ion channels underlying the anomalous MET currents}

Through what kind of ion channels could the anomalous MET current flow? Possibilities include the normal MET channels, but in an abnormal position or configuration so that they are not gated by tip links, or other mechanosensitive channels, or altogether different ion channels that are not related to the MET channel. A stretchsensitive current $\left(I_{\text {metL }}\right)$ of a few tens of pA that flows through nonselective channels (passing cations as well as anions) has been reported in response to mechanical stimulation by a glass probe or a fluid jet of the basolateral membrane of mature guinea pig OHCs, where it modulates electromotility (Rybalchenko and SantosSacchi, 2003). There is also some evidence for stretch-sensitive nonselective cation channels and potassium channels in the basolateral membrane of mature guinea pig OHCs, again with similarly small whole-cell currents (Ding et al., 1991; Iwasa et al., 1991). However, given that the anomalous MET currents are much larger, need strong mechanical stimulation close to the apical surface of the hair cell, occur well before the onset of electromotility around P8 in mouse OHCs (Marcotti and Kros, 1999) and are observed in both $\mathrm{OHCs}$ and IHCs, it is unlikely that they are due to these channels in the basolateral membrane.
Our finding of MET currents with inverse response polarity in mammalian hair cells at the earliest stage of their development (Fig. 7) bears comparison with recent observations on developing zebrafish hair cells (Kindt et al., 2012). Although MET currents were not measured in that study, $\mathrm{Ca}^{2+}$ entry into the hair cells was observed to occur early on in development when the bundles were moved away from the kinocilium. The $\mathrm{Ca}^{2+}$ responses in the early immature zebrafish hair cells were different from our $\mathrm{OHC}$ currents in that they were eliminated by BAPTA treatment and were absent in mutant zebrafish that lacked either $\mathrm{CDH} 23$ or PCDH15. The inverted responses in zebrafish hair cells were also not found in zebrafish mutants that lack normal kinocilia, which prompted Kindt et al. (2012) to propose that the kinocilial links, which are composed of PCDH15 and CDH23 like tip links but are of opposite orientation (Ahmed et al., 2006; Goodyear et al., 2010; Lelli et al., 2010), gate these currents. Given the resistance to treatment by BAPTA (and subtilisin) and the presence of the anomalous currents in mutants lacking tip-link proteins, we consider a location of the channels at the kinocilium, or an association with any other links, unlikely for mouse OHCs. The absence of any clear trend in the size of the anomalous MET currents with age up to P10, the oldest age tested (Fig. $7 C, D)$, also argues against this current being a transient, develop- 
mental phenomenon in mammalian hair cells. The abnormal kinetic properties of the currents, their instability, and the lack of a resting current point to an inefficient and variable engagement of the channels. Because the currents can be recorded once the hair bundle has been stripped of it links or mechanically destroyed, we propose that the ion channels underlying the anomalous current are located at the basal insertion points of the stereocilia or elsewhere along the apical membrane overlying the cuticular plate and are activated by the membrane shearing relative to the underlying cytoskeleton. Ion channels with reversal potentials close to zero and single-channel conductances similar to those of the MET channels have been found on the apical membrane of OHCs (Frolenkov et al., 2004).

\section{Molecular nature of the ion channels underlying the anomalous MET currents}

Our finding that the anomalous MET currents of OHCs are two orders of magnitude less sensitive to block by the aminoglycoside antibiotics DHS and neomycin suggests that the pore properties of the underlying ion channels are different. DHS is a permeant blocker of the normal MET channels (Marcotti et al., 2005), but the lack of release of block at extreme negative potentials suggests that this is not the case for the anomalous MET channels. The current-voltage curves of the anomalous MET currents are linear, unlike the normal MET currents which show a double rectification attributed to permeant block by the divalent cations $\mathrm{Ca}^{2+}$ and $\mathrm{Mg}^{2+}$ (Kros et al., 1992). Very similar anomalous MET currents have recently been reported for OHCs with mutations in the genes encoding the TMC1 and TMC2 proteins (Kim et al., 2013), which are both candidate for being subunits of the MET channel (Kawashima et al., 2011; Barr-Gillespie and Nicolson, 2013; Kim and Fettiplace, 2013; Pan et al., 2013). In homozygous TMC1 and TMC2 mutant mice the anomalous channels had a reduced $\mathrm{Ca}^{2+}$ permeability compared with the normal MET channels, but in contrast to the findings of the current study a relatively normal block by DHS (Kim et al., 2013). The reasons for the latter discrepancy are unclear and merit further investigation. The high $\mathrm{Ca}^{2+}$ permeability, large conductance and high-affinity permeant block by aminoglycoside antibiotics of normal MET channels have been attributed to the presence of a vestibule lined with negative charges at the extracellular side of the channel that concentrates
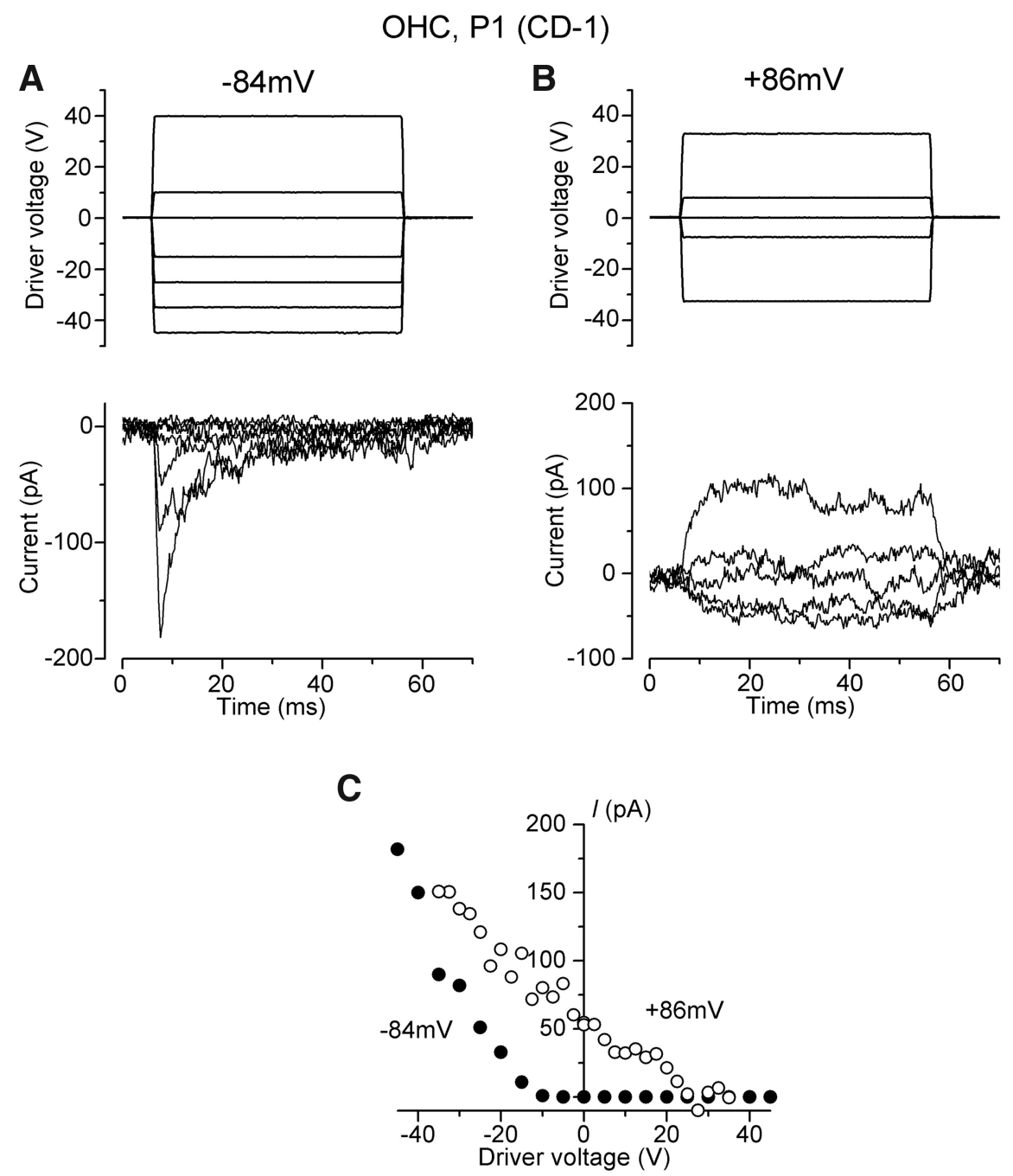

Figure 8. Anomalous MET currents in a normal P1 OHC in response to force steps. $\boldsymbol{A}, \boldsymbol{B}, \mathrm{MET}$ currents recorded at membrane potentials of $-84 \mathrm{mV}$ and $+86 \mathrm{mV}$ from a P1 apical-coil OHC from a CD-1 mouse. Transducer currents (inward at $-84 \mathrm{mV}$; outward at $+86 \mathrm{mV}$ ) are elicited by force steps in the negative direction (negative driver voltage). At $+86 \mathrm{mV}$ some MET channels are open at rest and are closed by positive force steps. Current declines strongly at $-84 \mathrm{mV}$ and slow onset kinetics are particularly evident at $+86 \mathrm{mV}$ (activation time constants $\sim 2.5 \mathrm{~ms}$ ). C, Absolute size of peak MET current as a function of driver voltage to the fluid jet at $-84 \mathrm{mV}$ (closed circles) and $+86 \mathrm{mV}$ (open circles), for a range of force steps.
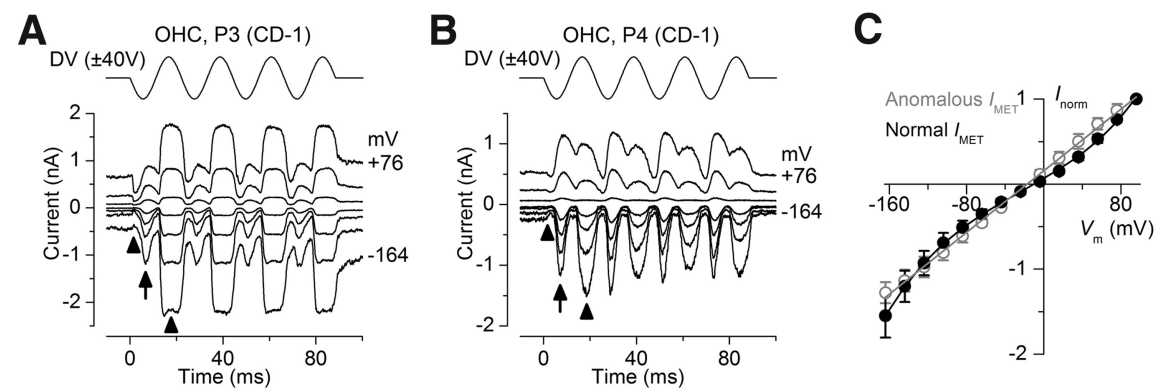

Figure 9. Normal and anomalous MET currents coexisting in the same cells. $\boldsymbol{A}, \boldsymbol{B}, \mathrm{MET}$ currents recorded from CD-10HCs in 1.3 mM extracellular $\mathrm{Ca}^{2+}$. Membrane potential stepped between -164 and $+76 \mathrm{mV}$ in $20 \mathrm{mV}$ increments from a holding potential of $-84 \mathrm{mV}$; for clarity only responses to every other voltage step are shown. Driver voltage (45 Hzsinusoid, $40 \mathrm{~V}$ amplitude) plotted above the current traces. In both cells, anomalous MET currents (arrow) are superimposed on the normal MET current (arrowheads), which has a component activated at rest that deactivates during the negative phase of the sine-wave stimulus. C, Currentvoltage curves of the normal and coexisting anomalous MET currents of four CD-1 OHCs (P3-P4) in $1.3 \mathrm{~mm} \mathrm{Ca}^{2+}$, including those of $\boldsymbol{A}$ and $\boldsymbol{B}$. Currents are normalized to values at $+96 \mathrm{mV}$ : normal MET current $737 \pm 249 \mathrm{pA}$; anomalous MET current $415 \pm 151$ pA. Fits are as follows: normal MET current $k=183 \mathrm{pA}, V_{r}=-10.1 \mathrm{mV}, V_{s}=38.5 \mathrm{mV}$, and $\gamma=0.46$; anomalous MET current straight line with slope of $3.76 \mathrm{pA} / \mathrm{mV}$. 
A

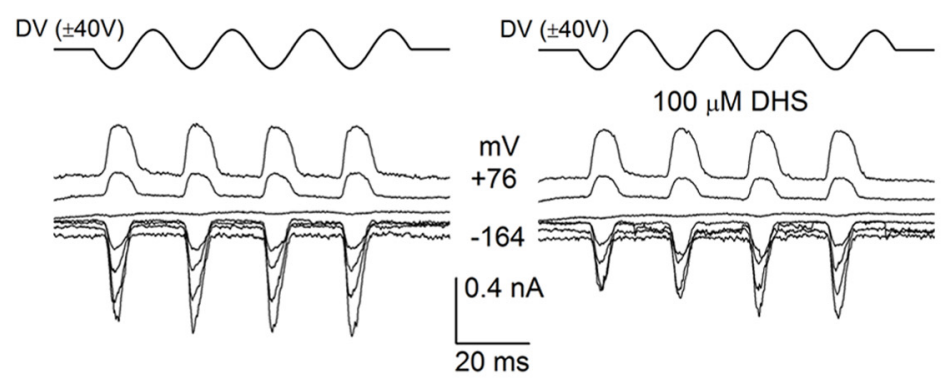

D

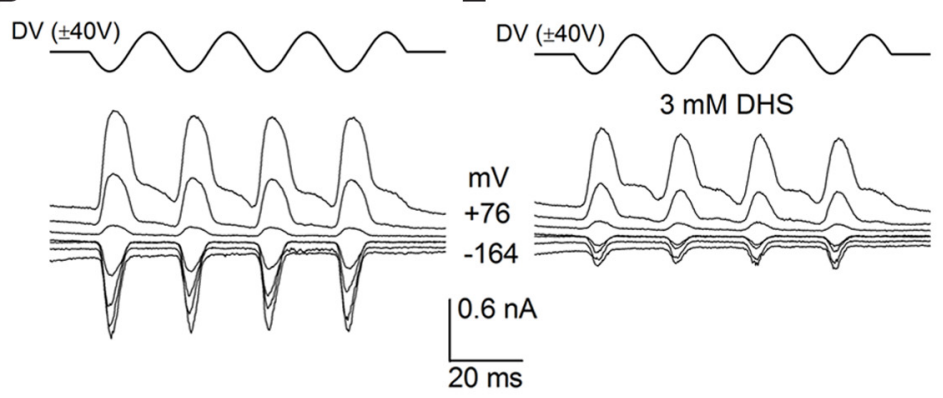

G

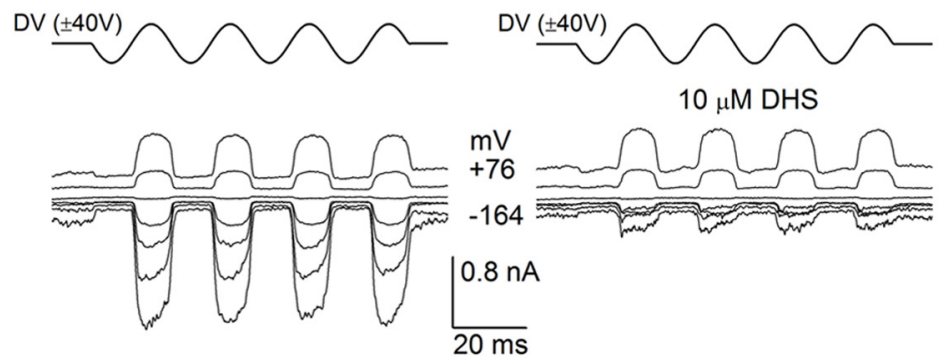

C

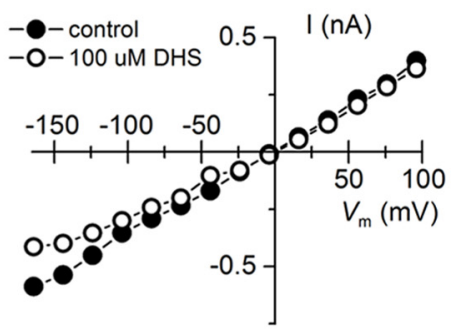

$\mathbf{F}$

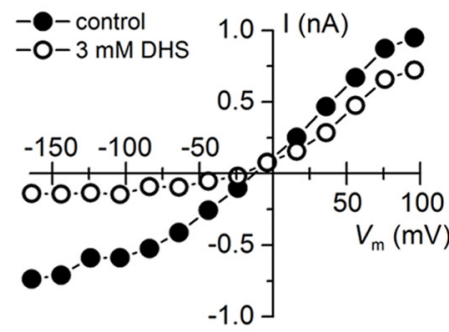

I

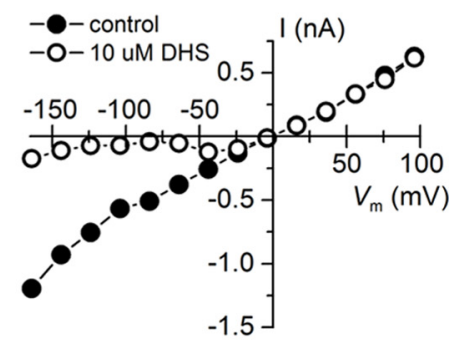

J

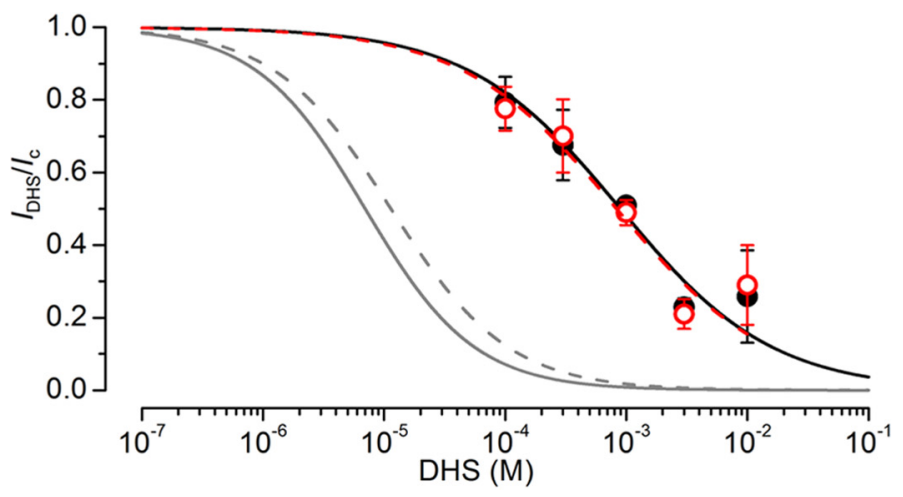

Figure 10. Reduced block by DHS of anomalous MET currents. $A, B$, Anomalous MET currents following BAPTA treatment recorded from a P2 CD-1 OHC before $(\boldsymbol{A})$ and during $(\boldsymbol{B})$ superfusion with a solution containing $100 \mu \mathrm{m}$ DHS. Membrane potential stepped between $-164 \mathrm{mV}$ and $+76 \mathrm{mV}$ in $20 \mathrm{mV}$ increments from a holding potential of $-84 \mathrm{mV}$. For clarity, only responses to every other voltage step are shown. Driver voltage ( $45 \mathrm{~Hz}$ sinusoid, $40 \mathrm{~V}$ amplitude) plotted above the current traces. C, Current-voltage curves of the cell of $\boldsymbol{A}$ and $\boldsymbol{B}$ before and during DHS. D, E, Anomalous MET currents following BAPTA treatment recorded from a P2 CD-1 OHC before $(\boldsymbol{D})$ and during $(\boldsymbol{E})$ superfusion with a solution containing $3 \mathrm{~mm}$ DHS. $F$, Current-voltage curves of the cell of $\boldsymbol{D}$ and $\boldsymbol{E}$ before and during DHS. $\boldsymbol{G}, \boldsymbol{H}$, Normal MET currents recorded from a P2 CD-1 OHC before $(\boldsymbol{G})$ and during $(\boldsymbol{H})$ superfusion with a solution containing $10 \mu \mathrm{m}$ DHS. $\boldsymbol{I}$, Current-voltage curves of the cell of $\boldsymbol{G}$ and $\boldsymbol{H}$ before and during DHS. J, Dose-responses curves for the block by DHS of the anomalous MET currents. Black closed symbols: $-84 \mathrm{mV}$, fitted with black continuous line to the Hill equation (see Materials and Methods), with $\mathrm{K}_{\mathrm{D}}=894 \mu \mathrm{mand} n_{\mathrm{H}}=0.69$. Red open symbols: $-164 \mathrm{mV}$, fitted with red dashed line: $K_{D}=832 \mu \mathrm{m} ; n_{\mathrm{H}}=0.68$. Block is not relieved at $-164 \mathrm{mV}$ (red dashed line overlaps with black line). Number of cells from left to right at both potentials: 4,6,2,4,2. For comparison the dose-response curves for DHS block of normal MET currents of apical-coil OHCs of CD-1 mice are shown (data from Marcotti et al., 2005). For normal MET currents block is reduced at $-164 \mathrm{mV}$ (dashed gray line: $\mathrm{K}_{\mathrm{D}}=11.4 \mu \mathrm{m} ; n_{\mathrm{H}}=0.90$ ) relative to $-84 \mathrm{mV}$ (continuous gray line: $\mathrm{K}_{\mathrm{D}}=7.0 \mu \mathrm{m} ; n_{\mathrm{H}}=0.96$ ).

and funnels cations into the pore (Beurg et al., 2006; van Netten and Kros, 2007; Pan et al., 2012). The low-affinity block by extracellular DHS of the anomalous MET currents is comparable to that of the block of the normal MET currents by intracellular
DHS at positive potentials (Marcotti et al., 2005; van Netten and Kros, 2007). The anomalous MET channels therefore seem to lack the vestibule of the normal MET channels. Although it is possible that the anomalous MET current is unrelated to the 
normal MET current, a more compelling possibility is that these anomalous currents represent a "reserve" population of MET channel precursors that are not usually evident in the presence of normal MET currents and can be observed when normal mechanotransduction is not yet established or cannot occur due to damaged or absent tip links. These hypothetical precursors have a permeation pore but lack a vestibule, which could conceivably be formed by TMC1 and TMC2 once the channels are in their normal position at the tips of the stereocilia. When a normal MET current is present the anomalous channels are only rarely observed (Fig. 9), suggesting that they are normally suppressed by an as yet unidentified mechanism.

\section{References}

Ahmed ZM, Goodyear R, Riazuddin S, Lagziel A, Legan PK, Behra M, Burgess SM, Lilley KS, Wilcox ER, Riazuddin S, Griffith AJ, Frolenkov GI, Belyantseva IA, Richardson GP, Friedman TB (2006) The tip-link antigen, a protein associated with the transduction complex of sensory hair cells, is protocadherin-15. J Neurosci 26:7022-7034. CrossRef Medline

Alagramam KN, Goodyear RJ, Geng R, Furness DN, van Aken AF, Marcotti W, Kros CJ, Richardson GP (2011) Mutations in protocadherin 15 and cadherin 23 affect tip links and mechanotransduction in mammalian sensory hair cells. PloS One 6:e19183. CrossRef Medline

Assad JA, Shepherd GM, Corey DP (1991) Tip-link integrity and mechanical transduction in vertebrate hair cells. Neuron 7:985-994. CrossRef Medline

Barr-Gillespie PG, Nicolson T (2013) Who needs tip links? Backwards transduction by hair cells. J Gen Physiol 142:481-486. CrossRef Medline

Beurg M, Evans MG, Hackney CM, Fettiplace R (2006) A largeconductance calcium-selective mechanotransducer channel in mammalian cochlear hair cells. J Neurosci 26:10992-11000. CrossRef Medline

Beurg M, Fettiplace R, Nam JH, Ricci AJ (2009) Localization of inner hair cell mechanotransducer channels using high-speed calcium imaging. Nat Neurosci 12:553-558. CrossRef Medline

Beurg M, Nam JH, Chen Q, Fettiplace R (2010) Calcium balance and mechanotransduction in rat cochlear hair cells. J Neurophysiol 104:1834. CrossRef Medline

Crawford AC, Evans MG, Fettiplace R (1989) Activation and adaptation of transducer currents in turtle hair cells. J Physiol 419:405-434. Medline

Crawford AC, Evans MG, Fettiplace R (1991) The actions of calcium on the mechano-electrical transducer current of turtle hair cells. J Physiol 434: 369-398. Medline

Ding JP, Salvi RJ, Sachs F (1991) Stretch-activated ion channels in guinea pig outer hair cells. Hear Res 56:19-28. CrossRef Medline

Frolenkov GI, Gorelik J, Richardson GP, Kros CJ, Griffith AJ, Korchev YE (2004) Single-channel recordings from the apical surface of outer hair cells with a scanning ion conductance probe. Assoc Res Otolaryngol Abstr 27:150.

Gale JE, Marcotti W, Kennedy HJ, Kros CJ, Richardson GP (2001) FM1-43 dye behaves as a permeant blocker of the hair cell's mechanotransducer channel. J Neurosci 21:7013-7025. Medline

Géléoc GSG, Lennan GW, Richardson GP, Kros CJ (1997) A quantitative comparison of mechanoelectrical transduction in vestibular and auditory hair cells of neonatal mice. Proc Biol Sci 264:611-621. CrossRef Medline

Goodyear RJ, Richardson GP (2003) A novel antigen sensitive to calcium chelation that is associated with the tip links and kinocilial links of sensory hair bundles. J Neurosci 23:4878-4887. Medline

Goodyear RJ, Marcotti W, Kros CJ, Richardson GP (2005) Development and properties of stereociliary link types in hair cells of the mouse cochlea. J Comp Neurol 485:75-85. CrossRef Medline

Goodyear RJ, Forge A, Legan PK, Richardson GP (2010) Asymmetric distribution of cadherin 23 and protocadherin 15 in the kinocilial links of avian sensory hair cells. J Comp Neurol 518:4288-4297. CrossRef Medline

Grati M, Kachar B (2011) Myosin VIIa and sans localization at stereocilia upper tip-link density implicates these usher syndrome proteins in mechanotransduction. Proc Natl Acad Sci U S A 108:11476-11481. CrossRef Medline

Iwasa KH, Li MX, Jia M, Kachar B (1991) Stretch sensitivity of the lateral wall of the auditory outer hair cell from the guinea pig. Neurosci Lett 133:171-174. CrossRef Medline

Kawashima Y, Géléoc GS, Kurima K, Labay V, Lelli A, Asai Y, Makishima T, Wu DK, Della Santina CC, Holt JR, Griffith AJ (2011) Mechanotrans- duction in mouse inner ear hair cells requires transmembrane channellike genes. J Clin Invest 121:4796-4809. CrossRef Medline

Kazmierczak P, Sakaguchi H, Tokita J, Wilson-Kubalek EM, Milligan RA, Müller U, Kachar B (2007) Cadherin 23 and protocadherin 15 interact to form tip-link filaments in sensory hair cells. Nature 449:87-91. CrossRef Medline

Kennedy HJ, Evans MG, Crawford AC, Fettiplace R (2003) Fast adaptation of mechanoelectrical transducer channels in mammalian cochlear hair cells. Nat Neurosci 6:832-836. CrossRef Medline

Kim KX, Fettiplace R (2013) Developmental changes in the cochlear hair cell mechanotransducer channel and their regulation by transmembrane channel-like proteins. J Gen Physiol 141:141-148. CrossRef Medline

Kim KX, Beurg M, Hackney CM, Furness DN, Mahendrasingam S, Fettiplace R (2013) The role of transmembrane channel-like proteins in the operation of hair cell mechanotransducer channels. J Gen Physiol 142:493505. CrossRef Medline

Kindt KS, Finch G, Nicolson T (2012) Kinocilia mediate mechanosensitivity in developing zebrafish hair cells. Dev Cell 23:329-341. CrossRef Medline

Kros CJ, Rüsch A, Richardson GP (1992) Mechano-electrical transducer currents in hair cells of the cultured neonatal mouse cochlea. Proc Biol Sci 249:185-193. CrossRef Medline

Kros CJ, Marcotti W, van Netten SM, Self TJ, Libby RT, Brown SD, Richardson GP, Steel KP (2002) Reduced climbing and increased slipping adaptation in cochlear hair cells of mice with Myo7a mutations. Nat Neurosci 5:41-47. CrossRef Medline

Lelli A, Asai Y, Forge A, Holt JR, Géléoc GSG (2009) Tonotopic gradient in the developmental acquisition of sensory transduction in outer hair cells of the mouse cochlea. J Neurophysiol 101:2961-2973. CrossRef Medline

Lelli A, Kazmierczak P, Kawashima Y, Müller U, Holt JR (2010) Development and regeneration of sensory transduction in auditory hair cells requires functional interaction between cadherin- 23 and protocadherin- 15 . J Neurosci 30:11259-11269. CrossRef Medline

Marcotti W, Kros CJ (1999) Developmental expression of the potassium current $I_{\mathrm{K}, \mathrm{n}}$ contributes to maturation of mouse outer hair cells. J Physiol 520:653-660. CrossRef Medline

Marcotti W, Johnson SL, Holley MC, Kros CJ (2003) Developmental changes in the expression of potassium currents of embryonic, neonatal and mature mouse inner hair cells. J Physiol [Erratum (2003) 550:996] 548:383-400. CrossRef Medline

Marcotti W, van Netten SM, Kros CJ (2005) The aminoglycoside antibiotic dihydrostreptomycin rapidly enters hair cells through the mechanoelectrical transducer channels. J Physiol 567:505-521. CrossRef Medline

Pan B, Waguespack J, Schnee ME, LeBlanc C, Ricci AJ (2012) Permeation properties of the hair cell mechanotransducer channel provide insight into its molecular structure. J Neurophysiol 107:2408-2420. CrossRef Medline

Pan B, Géléoc GS, Asai Y, Horwitz GC, Kurima K, Ishikawa K, Kawashima Y, Griffith AJ, Holt JR (2013) TMC1 and TMC2 are components of the mechanotransduction channel in hair cells of the mammalian inner ear. Neuron 79:504-515. CrossRef Medline

Peng AW, Effertz T, Ricci AJ (2013) Adaptation of mammalian auditory hair cell mechanotransduction is independent of calcium entry. Neuron 80:960-972. CrossRef Medline

Russell IJ, Richardson GP (1987) The morphology and physiology of hair cells in organotypic cultures of the mouse cochlea. Hear Res 31:9-24. CrossRef Medline

Rybalchenko V, Santos-Sacchi J (2003) $\mathrm{Cl}^{-}$flux through a non-selective stretch-sensitive conductance influences the outer hair cell motor of the guinea-pig. J Physiol 547:873-891. CrossRef Medline

Siemens J, Lillo C, Dumont RA, Reynolds A, Williams DS, Gillespie PG, Müller U (2004) Cadherin 23 is a component of the tip link in hair-cell stereocilia. Nature 428:950-955. CrossRef Medline

Söllner C, Rauch GJ, Siemens J, Geisler R, Schuster SC, Müller U, Nicolson T, Tübingen 2000 Screen Consortium (2004) Mutations in cadherin 23 affect tip links in sensory hair cells. Nature 428:955-959. CrossRef Medline

van Netten SM, Kros CJ (2007) Insights into the pore of the hair cell transducer channel from experiments with permeant blockers. Curr Topics Membr 59:375-395. CrossRef

Waguespack J, Salles FT, Kachar B, Ricci AJ (2007) Stepwise morphological and functional maturation of mechanotransduction in rat outer hair cells. J Neurosci 27:13890-13902. CrossRef Medline 